\title{
The EPO IPO: Transkaryotic Therapies, Amgen, and gene therapy
}

If you produce a protein in a cell that does not normally make the compound, by altering not the structural DNA but the regulatory sequence, is the product "natural" or "nonnatural?" The answer to that question-and one that will come from learned judges rather than scientists-could hugely influence the prospects of both established and emerging biotechnology companies. And it could mean life or death for some gene therapy strategies.

The question arises because Transkaryotic Therapies (TKT, Cambridge, MA) stated unequivocally in the share prospectus for its initial public offering (IPO) in October that its first product target is erythropoietin (EPO), the red blood cell growth factor drug, sales of which worldwide approached $\$ 2.9$ billion in 1995 . Using homologous recombination to insert regulatory DNA sequences ("gene activation"), TKT "turns on" the erythropoietin gene in cultured human skin cell lines that are suitable for commercial-scale manufacturing. It plans to begin clinical trials on EPO during the first half of 1997.

The conventional wisdom is that Amgen (Thousands Oaks, CA) owns the rights to EPO, at least in the United States. "EPO is the Mount Everest of [patents]," says Angus L. Macdonald, an analyst at Fahnestock \& Co. (Boston, MA). He believes that a second Amgen patent, granted in August 1996, which claims all nonnaturally occurring forms of the erythropoietin glycoprotein in effect shuts the door on EPO.

However, TKT-on the advice of its attorneys, Hamilton, Brook, Smith \& Reynolds (Boston, MA)-believes that its method of producing erythropoietin evades the patent. Some stock analysts concur: "We do not believe that any of these [Amgen's] claims would restrict TKT from using its producing gene activation technology to produce a naturally occurring version of the erythropoietin protein," says Tony Butler, a biotechnology analyst at Lehman Brothers (New York). Butler's view assumes that "gene-activated" EPO will be categorized as naturally occurring.

Amgen is not going to give TKT an easy ride. "We will defend our EPO patent position vigorously," says Amgen spokesperson David Kaye. The company has already (September 1996) sent TKT a warning letter concerning gene-activated EPO. And other, even bigger, companies are likely to defend their positions in EPO, too. Although Amgen and Johnson \& Johnson (New Brunswick, NI) are currently locked in litigation concerning the distribution of EPO revenues, Toni Claudio, a biotechnology analyst at Smith Barney (New York), predicts that in three or four years' time the two companies "will probably work

\section{Amgen is not going to give Transkaryotic Therapies an easy ride. "We will defend our EPO patent position} vigorously," says Amgen spokesperson David Kaye. The company has already sent Transkaryotic Therapies a warning letter concerning gene-activated EPO.

together to protect their [erythropoietin] market."

Alternatively, Amgen could borrow the strategy by which Genentech (S. San Francisco, CA) blocked competitors from the US human growth hormone market-by seeking an injunction against 'TKT's EPO.

TKT may face another patent battle over its gene activation technology. Cell Genesys (Foster City, CA) filed gene activation patents in 1989. "TKT is playing an extremely risky game," says Jeff Swarz, biotechnology analyst at CS First Boston (New York).

One of those Cell Genesys gene activation patents issued just last month, indicating that examiners at the US Patent and Trademark Office (Washington, DC) have judged that the company own the rights to gene activation in the areas that overlapped with Ares-Serono.

Cell Genesys does not intend to sue TKT for patent infringement at this time, according to its chief financial officer, Kathleen Glaub. In mid-November, the company received $\$ 5$ million as the result of the license agreement it renegotiated with Akzo (Oss, The Netherlands). The agreement gives Akzo rights to gene-activated follicle stimulating hormone (FSH) in infertility. This reassures Glaub of the strength of Cell Genesys' intellectual property: She believes
Akzo sought access to gene-activation "an insurance policy" to ensure its participation in the FSH market.

Hoechst Marion Roussel (HMR, Kansas City, MO) is playing both sides of this potential gene activation dispute. It owns about $13 \%$ of both TKT and Cell Genesys. Intriguingly, it has paid TKT \$42 million under a collaboration that includes the development and commercialization of gene-activated EPO and a second, undisclosed protein. An HMR spokesperson was unwilling to give either the company's interpretation of the patents surrounding EPO or to reflect on the relative merits of TKT or Cell Genesys in gene activation.

There is a broader question that arises from TKT's daring prospectus: Are broadly based patents, such as those that Amgen owns on methods for producing erythropoetin, going to hinder the development of newer approaches such as gene activation? Much of gene therapy, after all, depends on the production of therapeutic proteins within the human body. Are those nonnaturally occurring compounds?

Again, the legal position is unclear. Glaub believes that for a specific protein on which a company owned a patent "it certainly is possible" that courts would decide that the intrinsically produced molecule was nonnatural. But although she thinks that how one delivers a gene is an element in deciding what is natural, "what's really important is getting access to genes." Cell Genesys' approach is to avoid patented genes. "I think this gets to the heart of the whole issue for gene therapy," she says.

Although EPO is not a target for Cell Genesys, it is for Jeffrey Leiden. His group at the University of Chicago hopes to begin phase I trials of an erythropoietin gene therapy for anemia within the next year or so. "I think Amgen themselves have kept a very careful eye on the gene therapy field," he says. He believes that when the technology matures sufficiently to present commercial potential, Amgen will take an active interest.

Vicki Glaser

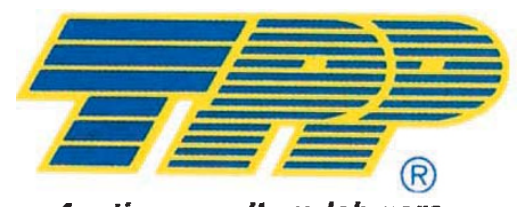

for tissue culture labware

Fax $++41 / 52-6814115$ 